\title{
Bone Bridges in the Groove for Middle Meningeal Artery
}

\author{
Puentes Óseos en el Surco para la Arteria Meníngea Media
}

\author{
Jorge Eduardo Duque Parra ${ }^{1,2}$; Eduardo Londoño Garzón ${ }^{1}$ \& Jhony Alejandro DiazVallejo ${ }^{1}$
}

\begin{abstract}
DUQUE, P. J. E.; LONDOÑO, G. E. \& DIAZ, V. J. A. Bone bridges in the groove for middle meningeal artery. Int. J. Morphol., 39(4):1012-1014, 2021.

SUMMARY: The middle meningeal artery is an important vessel that is distributed in the endocranium region, between greater wing of sphenoid by the homonymous groove. There are few references on the formation of bone bridges in their trajectory, an aspect of relevance in morphology. The present study included 100 skulls -dried and whole heads- of adults, removing the calvaria, and identifying the spinous foramen, through which the middle meningeal artery courses to determine the existence or not of bone bridges -unilateral, bilateral or absence- for the passage of this artery. Of 100 adult skulls analyzed, it was found at the level of the medial aspect of the greater wing of the sphenoid bone and in its internal table, $73 \%$ presented it and in $27 \%$ there was absence. Of the specimens with bone bridges, $39 \%$ were bilateral and of the latter, $34 \%$ was unilateral and $16 \%$ was on the right and $18 \%$ on the left. The bony bridge for the middle meningeal artery is an anatomical constant that must be evaluated in anatomical, clinical and surgical considerations.
\end{abstract}

KEY WORDS: Middle meningeal artery; Anatomy; Osteology.

\section{INTRODUCTION}

The vascular grooves that are usually seen in the internal table of the skull are bone depressions caused by arteries, meningeal veins and their branches; in its course along the surface of the dura mater, and sometimes, in the course of the middle meningeal artery, a bone tunnel (Taveras \& Wood, 1978; Dauber, 2007) is formed. The middle meningeal artery is a branch of the internal maxillary artery, which in turn is a component of the external carotid artery (Dauber; Standring, 2008). This middle meningeal artery supplies the dura mater via multiple branches, in addition to irrigating the periosteum (Chmielewski et al., 2013; Ellwanger \& de Campos, 2013). It usually penetrates the base of the skull through the spinous foramen continuing through a bone groove in the middle cranial fossa (Dauber; Standring). It curves over the greater wing of the sphenoid bone (Ellwanger \& de Campos) in which region it is associated with the pterion overlapping the groove for its anterior branch (Ma et al., 2012). It is distributed in addition to the anterior cranial fossa, in the supratentorial part of the posterior cranial fossa (Chmielewski et al.). Currently, the artery is incorporated into the periosteum layer adjacent to the dura mater and adheres to the cranial bones, an aspect that favors the development of common injuries in the course of said artery (Chmielewski et al.). Therefore, a wide craniotomy is required with the consequent ability to precisely locate the course of these blood vessels, being therefore a consideration in many neurosurgical procedures, a prerequisite in the evaluation of the trauma or pathology that affects the irrigated regions (Chmielewski et al.). As in the case of the epidural hematoma, that usually occurs between the internal table of the skull and that of the dura mater membrane, due to the fact of injuries of the head by a blow and in which between $85-95 \%$ of the patients, this type of trauma overload and fracture of the skull (Bruner \& Sherkat, 2008). The recognition of the middle meningeal artery in angiographic procedures is also important, in which other conditions have been generated, such as the manifestation of cardiotrigeminal reflexes that involve vomiting and bradycardia (Tamura et al., 2017), as well as its importance in procedures of endovascular treatments by embolization, curative arterial trans of non-cavernous arterial fistulas (Griessenauer et al., 2016). The aim of this work is to study the presence of bone bridges in the groove for the middle meningeal artery, since most of the vascular anomalies of the head and neck are not recognized throughout the life of a person, due to the result of atherosclerotic vascular disease, senile changes or some

\footnotetext{
${ }^{1}$ Departamento de Ciencias Básicas, Programa de Medicina, Universidad de Caldas, Manizales, Colombia.

${ }^{2}$ Departamento de Ciencias Biomédicas, Programa de Medicina, Universidad de Manizales, Manizales, Colombia.
} 
other pathological process, in which asymptomatic anomalies can become symptoms of clinical importance, which warrants an angiological examination and in some cases neurosurgical treatment (Lukic et al., 2001).

\section{MATERIAL AND METHOD}

The present study included 100 skulls -dry and whole headsof adults, from the anatomy laboratory, in the Medicine programs of the University of Caldas and the University of Manizales (Colombia). After a craniotomy, the calvaria was removed, then located on both sides at the level of the middle cranial fossa, the spinous foramen, which served as an anatomical mark to identify the continuation of the groove for the middle meningeal vessels at the level of the greater wing of the sphenoid bone, and it was observed the existence or not of bone bridges -unilateral, bilateral or absence.When identifying the existence of bridge, a nylon thread of $2 \mathrm{~mm}$ diameter was introduced by one end of the foramen of the bony bridge, until its exit by the opposite end. The nylon thread was removed to verify the existence of the tunnel formed as a bone bridge. In the case of specimens with vessels-whole heads-the continuation of the blood vessels in their course between the dura mater and the internal table was recorded, following the course of the middle meningeal artery towards the sphenoid greater wing, withdrawing the meninges and the consequent artery in case of finding a bony bridge at the level of the sphenoid greater wing.

\section{RESULTS}

Of 100 adult skulls analyzed, it was found at the level of the medial aspect of the greater wing of the sphenoid bone and in its internal table, 73 specimens presented it $(73 \%), 27(27 \%)$ did not present bony bridge in the groove for the middle meningeal artery (Figs. 1 and 2). Of the specimens that presented bone bridges, $39 \%$ of the specimens were bilateral, in $34 \%$ the presence of this furrow was unilateral, of which $16 \%$ were in the right side and $18 \%$ in the left side.

\section{DISCUSSION}

Although the vascular grooves for the arteries, meningeal veins and their branches can be seen in the internal table of the skull as depressions caused in their course by the surface of the dura mater and sometimes, in the course of the middle meningeal artery a tunnel is formed (Jones, 1912; Taveras \& Wood; Dauber), the latter are not described as anatomical variables and there are few notations found in the literature on this subject. One of these

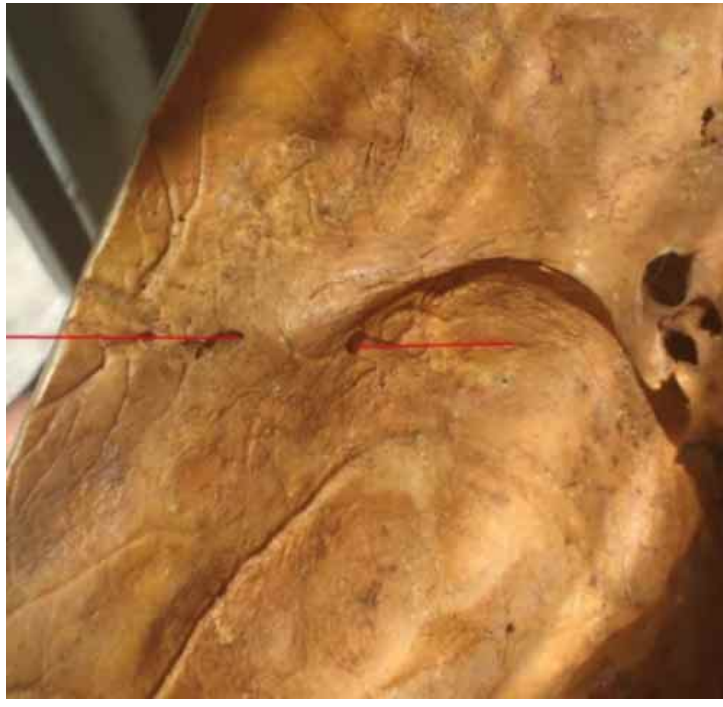

Fig. 1. Dry specimen of the skull, showing the groove for the middle meningeal artery, a bony bridge delimiting the entrance and exit foramina with red lines.

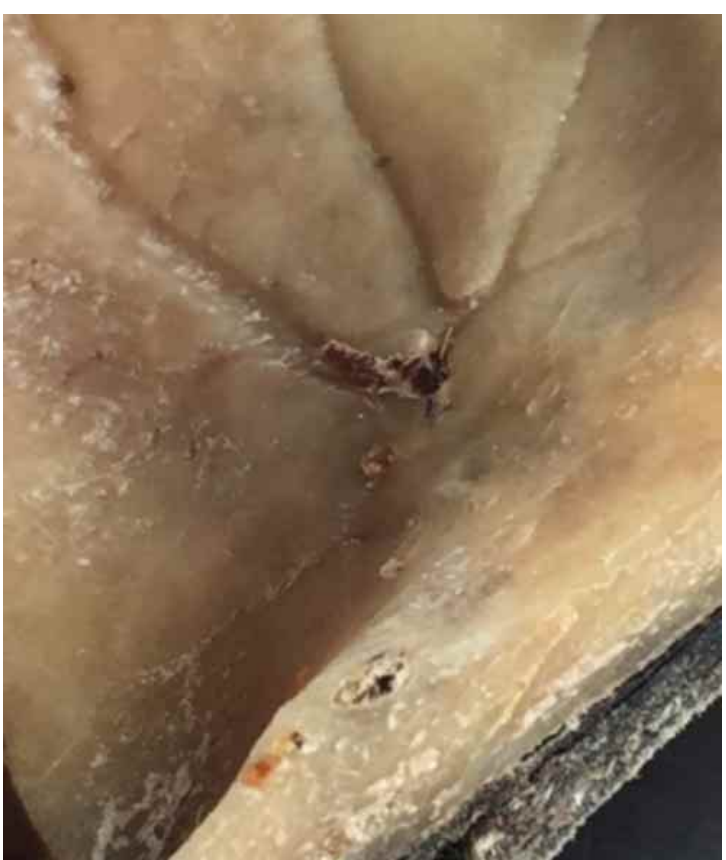

Fig. 2. Fresh specimen of the skull, in which the groove for the middle meningeal artery is observed and then, this entering through a bony bridge that is covering it, a remarkable detail in the lower part of the image in the internal table of the skull where the artery "enclosed" in the bony bridge.

annotations indicates that in a work performed on 39 skulls, the frontal branch of the middle meningeal artery can be located in said bone tunnel in $75.6 \%$ (Shimizu et al., 2008), a value very close to that achieved in this work, which was $73 \%$ that counted 
on the study of 100 skulls. Another work that was done on 50 adult skulls detects the presence of this bone bridge, but does not quantify it (Harthmann da Silva et al., 2013). This bone bridge is important, since its presence can be decisive when it becomes susceptible to tearing when fractures of the skull (Griessenauer et al.), noting that the artery, when incorporated in the periosteal layer of the dura mater, adheres to the cranial bones, favoring the development of common injuries in the course of the middle meningeal artery (Chmielewsk iet al.), so they should be taken into account. These findings have neurosurgical implications when accurately locating the course of these blood vessels, because of their high significance in a condition for many neurosurgical procedures, a prerequisite in the evaluation of trauma or pathology that affects the irrigated regions (Chmielewski et al.), as in the case of epidural hematomas (Bruner \& Sherkat) and in angiographic procedures of the middle meningeal artery (Tamura et al.). Larger studies should be carried out to confirm or disprove these findings, and also to establish whether these bone bridges are congenital or develop by alterations during the life cycle, especially in adulthood.There is a significant presence of bony bridges for the middle meningeal artery, especially at the level of the greater wing of the sphenoid, anatomical detail to be taken into account in the location of the course of the middle meningeal artery, in neuro procedures surgical or neuro-angiological exams, that can help establish the origin of the pain in migraine -that has not yet been adequately explained and remains the subject of vigorous debate (Shevel, 2009).

DUQUE, P. J. E.; LONDOÑO, G. E. \& DIAZ, V. J. A. Puentes óseos en el surco para la arteria meníngea media. Int. J. Morphol., 39(4):1012-1014, 2021.

RESUMEN: La arteria meníngea media se distribuye en la región del endocráneo entre el ala mayor del esfenoides por el surco para dicha arteria. Existen pocas referencias sobre la formación de puentes óseos en su trayectoria, aspecto de relevancia en el campo morfológico. El presente estudio incluyó 100 cráneos -secos y cabezas enteras- de adultos, a los que se les extirpó la calvaria e identificó el foramen espinoso, por donde discurre la arteria meníngea media, para determinar la existencia o no de puentes óseos -unilaterales, bilaterales o ausencia- en su interior. De 100 cráneos adultos analizados, se encontró puentes óseos a nivel de la lámina medial del ala mayor del hueso esfenoides y en su tabla interna en un $73 \%$ y en el $27 \%$ no hubo. De las piezas con puentes óseos, el $39 \%$ eran bilaterales y el $34 \%$ eran unilaterales; el $16 \%$ a la derecha y el $18 \%$ a la izquierda. El puente óseo de la arteria meníngea media es una constante anatómica que debe ser evaluada en consideraciones anatómicas, clínicas y quirúrgicas.

\section{PALABRAS CLAVE: Arteria meníngea} media;Anatomía; Osteología.

\section{REFERENCES}

Bruner, E. \& Sherkat, S. The middle meningeal artery: from clinics to fossils. Childs Nerv. Syst., 24(11):1289-98, 2008.

Chmielewski, P.; Skrzat, J. \& Walocha, J. Clinical importance of the middle meningeal artery. Folia Med. Cracov., 53(1):41-6, 2013.

Dauber, W. Pocket Atlas of Human Anatomy. $5^{\text {th }}$ ed. New York, Thieme, 2007

Ellwanger, J. H. \& de Campos, D. Abnormality of the foramen spinosum due to a variation in the trajectory of the middle meningeal artery: a case report inhuman. J. Neurol. Surg. Rep., 74(2):73-6, 2013.

Griessenauer, C. J.; He, L.; Salem, M.; Chua, M. H.; Ogilvy, C. S. \& Thomas, A. J. Middle meningeal artery: Gateway for effective transarterial Onyx embolization of dural arteriovenous fistulas. Clin. Anat., 29(6):71828, 2016.

Harthmann da Silva, T.; Ellwanger, J. H.; da Rosa Silva, H. T.; Moraes, D.; Dotto, A. C.; de Aguiar Viera, V. \& de Campos, D. Morphometric analysis of the middle meningeal artery organization in humansembryological considerations. J. Neurol. Surg. B Skull Base, 74(2):10812, 2013.

Jones, F. W. On the grooves upon the ossa parietalia commonly said to be caused by the arteria meningea media. J. Anat. Physiol., 46(Pt. 3):22838,1912 .

Lukic, I. K.; Gluncic, V. \& Marusic, A. Extracranial branches of the middle meningeal artery. Clin. Anat., 14(4):292-4, 2001.

Ma, S.; Baillie, L. J. M. \& Stringer, M. D. Reappraising the surface anatomy of the pterion and its relationship to the middle meningeal artery. Clin. Anat., 25(3):330-9, 2012.

Shevel, E. Middle meningeal artery dilatation in migraine. Headache, 49(10):1541-3, 2009.

Shimizu, S.; Hagiwara, H.; Utsuki, S.; Oka, H.; Nakayama, K. \& Fujii, K. Bony tunnel formation in the middle meningeal groove: an anatomic study for safer pterional craniotomy. Minim. Invasive Neurosurg., 51(6):329-32, 2008

Standring, S. Gray's Anatomy. The Anatomical Basis of Medical Practice. $41^{\text {st }}$ ed. London, Elsevier, 2008

Tamura, T.; Rex, D. E.; Marosfoi, M. G.; Puri, A. S.; Gounis, M. J. \& Wakhloo, A. K. Trigemino cardiac reflex caused by selective angiography of the middle meningeal artery. J. Neurointerv. Surg., 9(3):e10, 2017.

Taveras, J. M. \& Wood, E. H. Diagnóstico Neuro Radiológico. Buenos Aires, Médica Panamericana, 1978.

Corresponding author:

Jorge Eduardo Duque Parra

Calle 9D \# 1C-49

Manizales

COLOMBIA

E-mail: jorge.duque_p@ucaldas.edu.co

Received: 03-03-2021

Accepted: 14-05-2021 